\title{
Penile strangulation by multiple steel ball bearings: desperate situation-desperate measures
}

\author{
Iqbal Singh, ${ }^{1}$ Dhirendra Suman, ${ }^{2}$ Sanjay Gupta, ${ }^{3}$ Gaurav Garg ${ }^{4}$
}

${ }^{1}$ Urology Division, Department of Surgery, UCMS and GTB Hospital, New Delhi, India ${ }^{2}$ Department of Plastic Surgery, UCMS and GTB Hospital, New Delhi, India

${ }^{3}$ Department of Surgery, UCMS and GTB Hospital, New Delhi, India

${ }^{4}$ Department of Urology, King George's Medical University, Lucknow, India

Correspondence to

Dr Gaurav Garg,

gougarg@gmail.com

Accepted 9 October 2018

\section{DESCRIPTION}

A 33-year-old male patient was referred with progressive penile pain and swelling following history of self-placement of two industrial steel ball bearings for sexual gratification about 2 weeks back. The patient denied any history of trauma, insect bite, drug abuse and was dribbling urine, was sexually active and his history was unremarkable. Local examination revealed an engorged tender penis with two steel ball bearings strangulating the root of penis with pressure necrosis exfoliation/ pregangrene of penile skin (figure 1A). The blood biochemistry/urine reports were within normal limits and corporal blood gas analysis $\left(\mathrm{pO}_{2} 25 \mathrm{~mm}\right.$ $\mathrm{Hg}, \mathrm{pCO}_{2} 65 \mathrm{~mm} \mathrm{Hg}, \mathrm{pH} 7.18$ ) confirmed local ischaemia. Despite multiple attempts at corporal injections/aspirations (diluted norepinephrine), intermittent penile pneumatic pressure cuff inflation $(<80 \mathrm{~mm} \mathrm{Hg})$, Gigli wires and modified strings, the same could not be removed. Due to risk of penile gangrene (under anaesthesia, aseptic precautions/ensuring site safety/necessary safeguards and consent) after stabilisation of rings with an Allis forceps and countersupport with $\mathrm{BP}$ handle (figure 1B) we resorted to desperate measure of cutting the steel rings with a motorised electric ring (professional industrial marble cutting tool) BoschGDC120 under chilled saline drip for penile cooling (figure 1C). The chilled saline drip (lowered temperature to about $20^{\circ} \mathrm{C}$ that helped in reducing collateral thermal damage) and the rings were extricated successfully in $15 \mathrm{~min}$ (figure 1D)

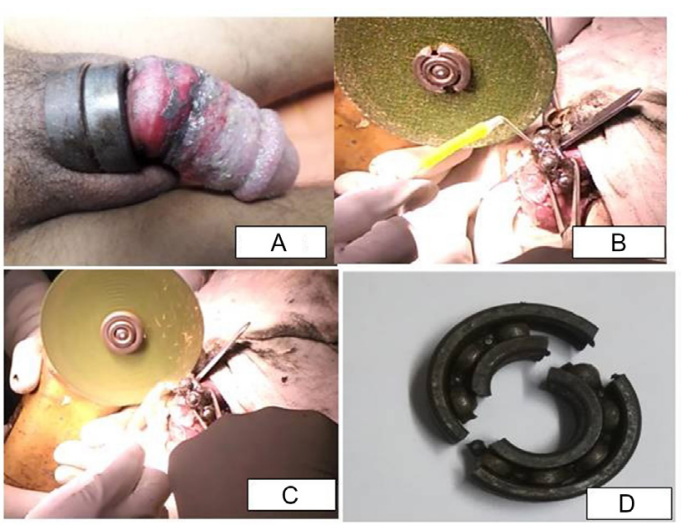

Figure 1 (A) Clinical image showing an engorged tender penis with two steel ball bearings strangulating the root of penis with pressure necrosis exfoliation/ pregangrene of penile skin. $(B, C)$ Clinical image showing cutting the rings with motorised industrial tool. (D) Clinical image showing retrieved ball bearings. and the patient was catheterised uneventfully. The swelling was considerably reduced after 2 days and the patient was discharged on Foley catheter after 1 week. On second week follow-up the patient was potent and developed urethrocutaneous fistula (UCF). He admits that he still experiences nocturnal penile tumescence and early morning erections. The patient is currently undergoing psychiatric counselling and treatment for UCF. Penile strangulation by steel ball bearings can occur uncommonly secondary to their placement for sexual gratification. ${ }^{1-3}$ If left untreated they have the potential to cause penile gangrene, urethral injury and erectile dysfunction. ${ }^{1}$ The management of penile strangulation injuries comprises urgent penile decompression to prevent penile necrosis. ${ }^{1}$ To ensure penile salvage in desperate situations where conventional measures fail there is compulsion to use desperate measures that may be unconventional and are difficult to avoid. ${ }^{13}$ If the urethra appears intact a per-urethral catheter may be placed else a suprapubic catheter may be placed for an uninhibited micturition. ${ }^{4}$ We do not promote the unauthorised use of any equipment/device/therapy and advocate the reader to exercise judicious care, extreme caution, follow all necessary procedures, training, credentialing and laws on the subject concerned as prevalent in the country of origin.

\section{Learning points}

- Strangulation of penis is an uncommon situation due to self-placement of a wide variety of strangulating objects for sexual gratification. Penile strangulation by multiple constricting metallic rings may lead to penile gangrene/necrosis/urethral injury/fistula and erectile dysfunction.

- Steel ball bearings encircling penis that cannot be removed may need cutting (with Gigli wire or motorised tools) to preserve penile function and prevent urethral injury.

Contributors GG and IS: concept, design, supervision, processing, writing manuscript and critical analysis. DS: supervision, processing, writing manuscript and critical analysis. SG: concept, supervision, writing manuscript and critical analysis.

Funding The authors have not declared a specific grant for this research from any funding agency in the public, commercial or not-for-profit sectors.

Disclaimer The authors specifically disclaim any liability for any loss or harm to whomsoever from the use of any information/ material in this manuscript whether explicit or implied.

Competing interests None declared. 
Images in...

Patient consent Obtained.

Provenance and peer review Not commissioned; externally peer reviewed.

\section{REFERENCES}

1 Singh I, Joshi MK, Jaura MS. Strangulation of penis by a ball bearing device. J Sex Med 2010;7:3793-7.
2 Silberstein J, Grabowski J, Lakin C, et al. Penile constriction devices: case report, review of the literature, and recommendations for extrication. J Sex Med 2008;5:1747-57.

3 Noh J, Kang TW, Heo T, et al. Penile strangulation treated with the modified string method. Urology 2004;64:591.

4 Baruah SJ, Bagchi PK, Barua SK, et al. An innovative surgical technique for treating penile incarceration injury caused by heavy metallic ring. Indian J Urol 2009;25:267-8.

Copyright 2018 BMJ Publishing Group. All rights reserved. For permission to reuse any of this content visit http://group.bmj.com/group/rights-licensing/permissions.

BMJ Case Report Fellows may re-use this article for personal use and teaching without any further permission.

Become a Fellow of BMJ Case Reports today and you can:

- Submit as many cases as you like

- Enjoy fast sympathetic peer review and rapid publication of accepted articles

Access all the published articles

Re-use any of the published material for personal use and teaching without further permission

For information on Institutional Fellowships contact consortiasales@bmjgroup.com

Visit casereports.bmj.com for more articles like this and to become a Fellow 